I Pontifical Catholic University of Rio de Janeiro (PUC-Rio), Postgraduate

Program in Communication, Rio de Janeiro, RJ, Brazil

everardo@puc-rio.br

II Pontifical Catholic University of Rio de Janeiro (PUC-Rio), Postgraduate

Program in Communication, Rio de Janeiro, RJ, Brazil

wacorbo@gmail.com

Everardo Rocha'

William Corbo"

\title{
A STAR PLAYER AND THE WORLD OF GOODS: SOCCER AND CONSUMPTION IN THE PUBLIC IMAGE OF LEÔNIDAS DA SILVA
}

THE GAME AND THE GOODS

In this article we analyse the place occupied by Leônidas da Silva ${ }^{\mathrm{I}}$ in the advertising market and his impact on consumption patterns in the I930s and I940s, the period of his career as a footballer. Our aim is to investigate the forms through which, in this context, consumption and the advertising narrative capitalized on football as a way to expand purchasing habits and, in the same movement, boost the popularity of the sport, as well as the interest and mobilization surrounding it. Leônidas, a black player in an era notable for explicit racial discrimination in football and in Brazilian society in general, was considered a celebrity, a frequent presence in reports and interviews that went far beyond the limits of the sports press. ${ }^{2}$ His habits, his humble origins, the events in his career, the polemics in which he became embroiled, the 'brilliant' displays of skill and the 'decisive' goals were constantly reported by the printed press - newspapers and magazines - and transmitted by the numerous radio broadcasters. Like other celebrities, Leônidas opened stores, starred in adverts, became the iconic face of diverse brands and lent his name to successful products, like Leônidas watches and cigarettes, and Diamante Negro (Black Diamond) chocolate, still sold today. The media's construction of his public image provides an insight into representations of the first sports celebrities in Brazil and, moreover, reveals a model of articulation between football and consumption that, conceived during this era, continues to permeate the contemporary imagination. 
As two phenomena central to our social experience, football and consumption evidently involve complex questions and open up a variety of different paths for academic investigation. Seen separately, both possess a palpable critical mass, the literature on consumption being more international, while Brazilian studies tend to prevail on the topic of football, partly because of the game's local importance. Consumption and related topics like fashion and advertising, for example, present a long tradition of studies beginning with Veblen (1965), Simmel (1904) and Sombart (I967), and followed by Lynd (1934, I936), Barthes (2003), Baudrillard (I993, I 99I), Douglas \& Isherwood (2004) and Sahlins (I979), up to more recent authors like McKendrick, Brewer \& Plumb (I982), Campbell (200I), McCracken, (2003) and, in the Brazilian case, Rocha (I985). ${ }^{3}$ Studies of football, despite the existence of works discussing the sociocultural importance of the sport in different contexts and countries (Duke, I99I; Armstrong \& Giulianotti, I999; Hughson et al., 2017), was first discussed in the Brazilian case by Freyre (1938, 2010). These studies continued with Guedes (I977), Miceli (I978), Araújo (I980), Rodrigues (I982) and DaMatta (I982, 2006) and include later works by Helal (I997), Toledo (I996, 2000, 2002), Pereira (2000) and Hollanda (2004, 20I0).

In the case of both themes, the studies cited above are mostly identified with the social sciences, particularly anthropology and sociology, since myriad works have been published on the two subjects by journalists, players, novelists and others, and listing them all would extend far beyond the limits of the present article. What interests us more closely are those studies that examine the relations between football and consumption, whether focused on questions of sport as business (Damo, 2008, 2009, 2012), or on the specific issues surrounding major sporting events (Damo, 20I I; Damo \& Oliven, 20I4) or on the interactions between the game, the mass media and advertising narratives (Sodré, I977; Gastaldo, 2002; Amaro, Helal, 20I4; Helal et al., 20I4).

Our work here adopts a different approach since it focuses especially on the approximation between football and consumption from the viewpoint of understanding how, in the first half of the twentieth century, these two phenomena established a model of articulation through the advertising industry's recruitment of outstanding footballers, a process that saw the transformation of these players from the 'football world' into stars of the 'world of goods.' In this sense, the model first developed with Leônidas is emblematic since his fame and prestige, the idolization that he provoked and his heroism, continually and incisively expressed in the media, provide an insight into this experience of constructing sports celebrities capable of mobilizing crowds and selling all kinds of products and services, including the persistence of this same model today within much the same logical parameters.

To deepen the discussion on the articulations between football and consumption through the example of Leônidas, this article is divided into three 
parts. In the first our idea is to explore some of the pivotal moments in the player's career and his consecration as Brazilian soccer's biggest name and idol in the first half of the twentieth century. In the second part we debate the role of the sports press and the media in general in the construction of Leônidas's public image as a national hero and a representative of core elements of Brazilian culture. Finally, we turn our attention to analysing how the football star was transformed into a celebrity able to attract huge crowds, heavily influencing the social life of his time and working actively in the advertising market to promote stores and sell products like cigarettes, watches and chocolate.

As a cultural and collective phenomenon wrapped in symbolism, consumption gives meaning to social life and provides the codes that enable us to comprehend and act in the world in which we live (Douglas \& Isherwood, 2004). Football, as a social drama (DaMatta, I982), produces - along with its draws, wins and defeats - narratives and myths capable of elaborating images of idols and legendary heroes that fill the pages of the sports press and the media in general. This article reveals some of the fundamental aspects of the emergence of a model of articulation between consumption and football that has informed purchasing practices and relations with the game to the present day. A detailed look at the history of football in Brazil reveals how, even in the first decades of the sports professionalization, the country's players appeared frequently in articles, special reports and interviews in newspapers and magazines and on the radio. The football stars of the I930s and I940s generated huge amounts of public interest. Idolized wherever they went, they drew large crowds and became celebrities with a strong popular appeal. Despite being a black footballer in a context of widespread racial discrimination, being polemical (or perhaps because of this) and having his attitudes continually criticized by many, Leônidas, the leading player of this generation, was the country's biggest sports celebrity, capable of acting in the sphere of consumption and boosting the sales of a range of products (Gordon, I995).

\section{A STAR IN THE FOOTBALL UNIVERSE}

Born in I9I3, in Rio de Janeiro, Leônidas began to display his skills with the ball at his feet in the kickabouts played in the district of São Cristóvão, a suburb of the city where he lived for most of his childhood and adolescence. In I930, before completing the age of 17 , he made his debut as a soccer player at Sírio Libanês, a modest club from the city's Tijuca district. The following year, Leônidas was taken by his former trainer at Sírio, Gentil Cardoso, to Bonsucesso, which offered better conditions for him to develop his talent than at the previous club. Despite failing to win the I93 I Rio Championship, Bonsucesso attracted considerable attention for the outstanding performance of its players, finishing seventh place in a competition that included teams of the renown of América, Bangu, Botafogo, Flamengo, Fluminense and Vasco da Gama. At Bonsucesso, 
playing alongside other black players who would later become his team mates in the Rio squad and Brazil's national side, Leônidas's talent became clearly apparent to supporters and journalists, who boasted of the emergence of one of the best prospects for Brazilian football (Pereira, 2000).

The year I93 I marked "definitively the name of Leônidas in the Brazilian football setting. Despite playing for the modest Bonsucesso, he would soon become known on all Brazil's football pitches" (Ribeiro, 2010: 36). After the standout performances for his club and winning the Brazilian Club Championship for Rio de Janeiro, Leônidas was invited to wear the jersey of the Brazilian team in the I932 Rio Branco Cup along with other players who, like him, had shone in the Rio teams. Accompanied on the pitches by stars like Domingos da Guia, Oscarino, Gradim and Jarbas, he led the national side in its historical win over Uruguay, scoring both goals in Brazil's 2-I victory. Winning the 1932 Rio Branco Cup proved to be a landmark in the history and self-esteem of Brazilian football, as well as a watershed in the career of Leônidas, quickly identified as the team's star player and hero of the national squad (Pereira, 2000; Ribeiro, 2010).

The enthusiasm generated by winning the title was so great that on their arrival back in Rio de Janeiro, the players were welcomed by a jubilant crowd parading through the city's streets. During the celebrations, driving in an open car along Rio Branco Avenue, they were able to feel at close hand the warmth of thousands of people cheering deliriously, Leônidas and Domingos in particular. From that moment, as champions of the Rio Branco Cup wearing the Brazilian team shirt, the two black players and the Rio suburb became consolidated as the major stars of the nation's football:

Domingos and Leônidas, carried by the crowd at the moment they landed, were the most celebrated. Applauded with 'real enthusiasm' by the supporters lining the avenue in a display that 'was as powerful as it was spontaneous,' they attracted most of the attention and delirium of the fans. Recognized as legitimate representatives of Brazil, they were greeted along with the other players by the head of the provisional government himself, Getúlio Vargas - who, as the delegation passed in front of the Catete palace, remained on the palace balcony waving to the champions until the parade had passed by (Pereira, 2000: 324).

The success of players like Leônidas and Domingos prompted the wealthy Uruguayan football clubs to spare no expenses in signing them. While the defender agreed a transfer to Nacional and became a club idol, Leônidas signed a contract to wear the Peñarol shirt. On December the $7^{\text {th }}$ I932, the Jornal dos Sports reported Leônidas's final words as he embarked for Uruguay: “Through Jornal dos Sports I say my farewell to the Rio people and the enthusiastic 'fans' who I know I'm going to miss." At the new club, he found it very difficult to adapt. He was hit by a series of injuries and his performance failed to match expectations, since "the freedom granted to players by Uruguayan clubs [...] was a problem for Leônidas, who, in order to keep fit in Brazil, had needed to be kept under constant surveillance"4. 
Returning to Brazil in 1934, he agreed a contract with Vasco da Gama, who, in addition to Leônidas, invested in the hiring of other highly successful black players like Fausto - the 'Black Marvel' - and later Domingos himself. Leônidas stayed at Vasco da Gama for a short time only, since amid the political dispute between amateurism and professionalism in Brazilian football, he decided to sign with the Brazilian Sports Federation (Confederação Brasileira de Desportos: $\mathrm{CBD}$ ) to play for the national team at the I934 World Cup, held in It aly. ${ }^{5}$ After a terrible preparation (Pereira, 2000; Ribeiro, 2010), the team was eliminated in the first match after a I-3 loss to Spain. Scorer of Brazil's only goal, Leônidas managed to stand out amid the disastrous Brazilian campaign and showed glimpses of the football that would enchant the world four years later.

After the World Cup, Leônidas began to wear the jersey of Botafogo, the club with whom he established himself as a star by winning the Rio championship in I935. Despite the title, Leônidas became involved in public polemics with the Botafogo directors and suffered from the strong racial prejudice, which led to the fact that, at most of the big clubs, directors and fans were opposed to the presence of black players in their sides (Gordon, I 995; Pereira, 2000; Souza, 2008; Ribeiro, 2010). Unhappy at Botafogo and at war with the directorate, he was sold to Flamengo, which planned to assemble a powerful team for the I 936 season and end an eight-year drought without winning the Rio championship. The arrival of the Diamante Negro (Black Diamond) ${ }^{6}$ at Flamengo was greeted with enthusiasm by the club's already huge fanbase, by widespread press coverage, by the anxiety of the club directors, and by expectations concerning his future relationship with the trainer Flávio Costa, famed for taking a hard line with players. At his new club, Leônidas met up again with former team mates like Jarbas, Fausto and Alfredinho. In a short while, Flamengo had managed to "reunite Rio de Janeiro's most famous trio of black players: Domingos, Leônidas and Fausto" (Ribeiro, 20Iо: IоI). Over the following years, Leônidas showcased his skills and led Flamengo in memorable games in the Rio Championship, especially against Fluminense, whose team featured top players from São Paulo, like Hércules, Romeu, Lara, Batatais, Ozorimbo and Russo (Ribeiro, 2010).

Flamengo's success, the magic of his talent with the ball at his feet, the fame and social prestige all helped generate huge expectations for the player's performance at the I938 World Cup, hosted in France. This time the Brazil squad was filled with the country's best players and underwent preparation for the event, trying to avoid the mistakes that had contributed to the failure four years earlier. Brazil opened by beating Poland 6-5, drawing I-I with Czechoslovakia and then beating the same team 2-I to reach the semi-final against Italy. In the decisive game, Leônidas, injured, stayed on the bench and watch Brazil's defeat by two goals to one - a result heavily questioned by the players and the sports press due to refereeing errors (Pereira, 2000; Souza, 2008; Ribeiro, 2010). Disappointed with their elimination, the Brazilian players beat Sweden 4-2 in the 
match for third place. As far as Leônidas's performance in the World Cup was concerned, all expectations were exceeded. Emerging as the tournament's top scorer and biggest star, he was celebrated as the hero in the Brazilian team's unprecedented and surprising third place. The Black Diamond was hailed as "the best centre-forward in the world!"7 and acclaimed by the entire French press. According to Raymond Thoumazeau, columnist of the magazine Match, "This rubber man possesses the diabolical gift of being able to control the ball lying down or in the air and shoots explosively when least expected." ${ }^{8}$

Returning from the World Cup, ${ }^{9}$ Leônidas became established as the greatest Brazilian footballer currently active (Ribeiro, 2010). In the same year he won the Brazilian championship with the Rio squad (the Seleção Carioca). In I939, he led Flamengo to victory in the Rio Championship. The following year, however, his relationship with the club began to unravel, his knee showed signs of strain, and the fans became more impatient and mistrustful of their star striker. Despite the criticism, Leônidas scored 30 goals in the 1940 Rio Championship. Later, in I94I, injured and immersed in disputes with the Flamengo directors, his contract was suspended by the club. In the same year, he was convicted for illegalities on his military certificate and spent time in prison in Vila Militar, where he was idolized and admired as the country's top footballer. After the spell in prison, the fight with Flamengo became even more accentuated and frequently spilled into the newspapers. The press would publish full-page reports, listing the criticisms made by the directors concerning the player's behaviour, and, on the other side, Leônidas's accusations against the club's agents (Ribeiro, 20Io).

The dispute with Flamengo ended in 1942 when Leônidas transferred to São Paulo, the club for which he would play until the end of his career in I 949. In his debut appearance, a match against Corinthians, his importance to Brazilian soccer and his consolidation as a star with a huge capacity for social mobilization were clearly apparent. More than 70,000 people packed the Pacaembu stadium to watch the first game of the Black Diamond wearing the São Paulo tricolour shirt, beating the stadium's attendance record in the process (Ribeiro, 20I0). Between I942 and I949, Leônidas scored I44 goals in the São Paulo jersey and won the São Paulo championship in I943, I945, I946, I948 and I949. By the end of his career, though still considered the best player competing on Brazil's pitches, he was not selected by the coach Flávio Costa to dispute the I950 World Cup held in Brazil. After the national team's tragic loss to the national team to Uruguay at the Maracanã itself, many said that had Leônidas been playing, history would have turned out differently.

\section{LEÔNIDAS, THE MEDIA AND VISIONS OF PARADISE}

Leônidas's career unfolded in the context of intense political, economic and cultural transformations in Brazilian society (Pandolfi, I999; Fausto, 2006). In I930, the year when he debuted as a football player, Getúlio Vargas rose to 
power through a successful revolutionary movement that had finally overcome the logic of alternating power between mineiros (the cattle ranching elite from Minas Gerais) and paulistas (coffee growers from São Paulo state) during the period of the Old Republic - also jokingly known as the "republic of coffee with milk." Vargas would remain in command of the country, oscillating between more democratic and more authoritarian conducts until I 945, when the Estado Novo (New State) dictatorship came to an end. During this period, a nationalist politics was implemented, labour laws instituted, state companies created, public works funded and a particular national identity modelled and propagandized incisively. In a nutshell, Getúlio Vargas sought to unify the country around a collective project and an ideology that would unify all Brazil's cultural diversity in pursuit of the development of national society and, above all, the construction of a specific national identity. In this process, State and football became closely merged, the sport transformed into one of the main propaganda elements for the Brazil project (Souza, 2008).

At diverse moments, the alliance between State and football became clearly apparent. In 1935, for example, during the clash between clubs and organisations that advocated amateurism on one hand and professionalism on the other, the federal government intervened to create a harmonious setting and unify the separate interests into a common project. In the same year, representatives of the federal government began to closely accompany the development of football in Rio de Janeiro city, setting rules and applying penalties for clubs who breached their contracts with professional players (Pereira, 2000). Then in 1936, in another instance of approximation between State and football, the clubs asked the Vargas government once again to mediate between the groups, clubs and associations that were clashing over the issue of professionalism or amateurism in Brazilian football. All these events showed the involvement of the Brazilian presidency and the State's broader interest in the direction taken by Brazilian football (Pereira, 2000; Souza, 2008).

The transition process from amateurism to professionalism was fundamental to the increase in the number of black footballers playing for the big clubs and for the Brazilian national side. The regulations introduced to professionalize soccer were also a way to "dissipate the racial prejudice and discriminations that surrounded players like Leônidas and Gradin" (Pereira, 2000: 325). This was an important condition for augmenting the popularity of the game and the quality of the show, and, moreover, for legitimizing the notion of a Brazil that valorised its internal differences. As Gordon (1995) emphasizes, the influx of black players into football did not end racial discrimination since the main clubs would not allow them - now treated as remunerated employees - to frequent their social areas. However, professionalization did create the space to minimize preconceptions of racial inferiority. The increasing presence of black players like Leônidas in the classic matches between the country's top clubs and in the suc- 
cesses of the national team represented the idea of a harmonious Brazil, capable of uniting distinct classes and groups around a common project.

In this movement, the sports press of the period, especially the journalist Mário Filho, campaigned hard for the professionalization of the sport and for a greater presence of black players in Brazilian soccer (Leite Lopes, I994). While Leônidas was gracing the nation's pitches, the sports press was expanding at a breath-taking pace and football invaded the newspaper pages, radio programs and day-to-day conversations in the city. Since the end of the I92os and the advent of radio, football had reached an ever-widening public that had previously lacked any access to matches, events or information on the sport. In the same period, the expansion of the specialized press was also significant. According to research conducted by the National Department of Trade, sports periodicals leapt in number from five journals in I9I 2 to fifty-eight in I930 (Souza, 2008). Important publications emerged, like Jornal dos Sports, Rio Sportivo and Mundo Esportivo, and the journalist Mário Filho became a prominent figure in football's development and expansion (Leite Lopes, I994; Pereira, 2000; Souza, 2008).

In I93I, with Roberto Marinho taking command of the newspaper $O$ Globo, Mário Filho became responsible for its sports section and from that moment the talent of black players like Leônidas and Domingos was extolled in the paper's day-to-day coverage and special reports. Then in I936, Mário Filho bought Jornal dos Sports, founded five years earlier by Argemiro Bulcão. Under his direction, the newspaper began to be printed on pink paper and transformed into one of the main outlets of the national sports media. In I938, together with Roberto Marinho, he launched O Globo Esportivo. More than a journalist, Mário Filho had become the main disseminator of football in Brazil and effusively championed causes that valorised the presence of black players at the top clubs and in the national side (Leite Lopes, I994). For him, these players were the true representatives of the Brazilian style of playing football (Rodrigues Filho, 20 Io). Discussing Mário Filho, Pereira (2000: 33I) emphasizes that:

Since I93I, the journalist had already emphasized in the pages of O Globo the "bewildering mobility and rapid play" typical of players like Leônidas, recognized even by his opponents. Like him, other columnists were focusing their attention in those years on the first emergence of a "characteristically Brazilian technique of extremely quick play and dazzling improvisation in the most tricky moments" - which distinguished the playing style of the Brazilian athletes from the technique and discipline learnt from Europeans.

For journalists like Mário Filho, Brazilian football was seen as "equal in power and art, if not superior, to the football played in both Argentina and Uruguay" (Pereira, 2000: 33I). In this context, the presence of black players, previously seen as a "shameful defect of the sport practiced in the country" (Pereira, 2000: 33I) became glorified by the press as "the big differentiating factor of Brazilian football - helping decisively in the creation of a national 
playing style" (Pereira, 2000: 332). Hence the sports journalism of the period, led by Mário Filho, attributed the black footballers with characteristics that configured what would become the specifically Brazilian way of playing soccer. In the press narratives, idols like Leônidas and Domingos, for example, personified the most important and enchanting characteristics of Brazil's football.

Along the same lines, an essential role was played by the sociology of Gilberto Freyre, which takes Brazilian society to be marked by a series of economic and cultural paradoxes - European and African culture, African and indigenous, Jesuit and farmer, master and slave, university educated and illiterate. These paradoxes expose fundamental dilemmas, ambiguities, dualities and divisions in Brazil's culture. Faced with this antagonistic scenario, however, the peculiar feature of Brazilian culture is the attempt to balance these opposing forces, elaborating a positive mixture in which the oppositions are equilibrated and contribute to the forming of an enriched culture (Araújo, 1994). For Freyre (1975: 52): "Nowhere, perhaps, can we observe with equal freedom the encounter, intercommunication and even harmonious fusion of diverse or even antagonistic cultural traditions as in Brazil."

Turning to Brazilian football, he emphasizes the contributions of black players to our particular way of playing the game, differing from the well-drilled style of the British "to turn into the dance full of irrational surprises and Dionysian variations that it is" (Freyre, 20Io: 25). Domingos da Guia, for example, had added "a bit of samba, a bit of Bahian molecagem and even a bit of Pernambucu capoeira or Rio malandragem" (Freyre, 2010: 25), while Leônidas performed a kind of Bahian dance on the pitch. This image of Brazilian football and the depictions of Leônidas in the media can be summarized by Mário Filho's narration of the goal scored by the forward in the match against Poland in the 1938 World Cup, when "Leônidas kneeling, tying his bootlace, the Polish keeper takes the goal kick, Leônidas stands up, shoots the ball, goal to Brazil" (Rodrigues Filho, 2010: 2I8). The representation was one of improvisation, trickery, mischief and inventiveness in a pure state.

\section{A CELEBRITY IN THE WORLD OF GOODS}

Leônidas was the essential reference point in creating and sustaining a fundamental representation of a specifically Brazilian style of playing football - inventive, naturally talented, improvised, full of genial heroes and national saviours (Rocha, 2003) - which reinforces a certain desired image of Brazilian culture. In this sense, their exploits on the pitch wearing the shirts of the top clubs and the national team, the events in their personal lives, their injuries, the polemics and the transactions all formed part of the press routine of their time, shaping the Brazilian cultural imaginary. With his incisive and constant presence in the media, Leônidas became firmly established as one of the most important celebrities of the I930s and I940s. If "celebrities flaunt whatever a 
particular society, at a particular moment, valorises" (França, 20I4: 25) and football is a privileged space in which cultures talk about themselves (DaMatta, I982), the Black Diamond represented a particular contemporary interpretation of Brazil, emphasizing the positivity of mixture, which would mark a particular ideological vision of Brazilianness. As a media representation, therefore, Leônidas helped construct an image of Brazil as a harmonious fusion of opposites, capable of overcoming differences and uniting the best of diverse worlds. This Brazilian image persists even today, mobilized in advertising narratives and the mass media, in products like soap operas, studio programs, interviews and the press in general (Rocha, 2006).

During his career as a football player between the I930s and I940s, everyone wanted to talk about Leônidas; his popularity and capacity to attract crowds led to the publication of innumerable reports on his life, habits and behaviours that went far beyond soccer (Ribeiro, 2010). The newspaper O Globo, among many other stories on the player, published "A 'shoot' in the bachelor life," reporting the marriage of Leônidas, which "included the presence of innumerable admirers of the popular footballer, noting among those attending the president of the club [Flamengo], Mr. Bastos Padilha, as well as other direc-

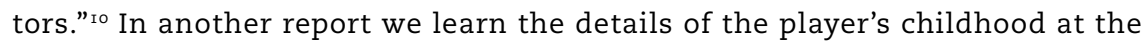
school where he studied, where he was known as a 'ghost of the teachers.' ${ }^{\text {II }}$ Indeed, when they needed to sell newspapers and magazines or increase the radio audiences, all of them talked about Leônidas:

The journalists relied on Leônidas to fill their copy. 'The Black Diamond visiting our offices.' Visiting houses. Wherever the newspaper went, Leônidas went. The fan would open the sports pages and there was Leônidas, smiling at him like an old friend. The fan could cross his legs, recline in the chair, not even remove the toothpick from his mouth to have a chat with the inventor of the bicycle kick. Completely at home (Rodrigues Filho, 2010: 214).

Leônidas's fame traversed barriers and surprised even those who had followed his career closely. For the journalist Mário Rodrigues Filho (2010: I94I95), the welcome given to the players who won the I932 Rio Branco Cup illustrates the fame and idolization of the striker Leônidas, who, though still young at the time, already appeared as the biggest star of Brazilian football:

The CBD joined in with the tributes to Leônidas, everyone just wanted to know about Leônidas and Domingos. One had scored two goals, the other had not let a single ball past. The symbols of Brazilian football: Domingos and Leônidas.There was another: Fausto. But Fausto was faraway, he had not competed in the Rio Branco Cup. So Domingos and Leônidas grabbed all the attention. Especially Leônidas.

During the victory parade, it was impossible to walk down Rio Branco Avenue, it was like the third day of Carnival. Leônidas was on the lowered hood of an automobile, embracing the Rio Branco Cup. 'Leônidas! Leônidas! Leônidas!' 
At the I938 World Cup, Leônidas was the star player of the Brazilian team. The extent of his fame was such that some journalists claimed that "the most famous man in Brazil was Leônidas da Silva, not Getúlio Vargas, the president of Brazil" (Ribeiro, 20I0: I I2). On the team's return to the country:

The Brazilian squad would arrive in a city, the shops would close, and people would swarm into the street to carry Leônidas in triumph. The other players were inside the automobiles, the automobiles drove slowly, at funeral pace, accompanying the Leônidas procession. And everyone thought that they were paying tribute to the Brazilian team. All the players turned up, but the tribute was for Leônidas, just for Leônidas to receive medals, baskets of flowers, club banners, Brazilian flags. The others watched on, squeezed into a room bursting with people, as though they weren't players (Rodrigues Filho, 2010: 219).

When they arrived in Recife, the Brazilian stars were greeted by a crowd of Pernambuco fans. Amid the players, it was Leônidas who would receive the main tributes. As the newspaper O Globo reported: "Leônidas, the 'Black Diamond,' who shone on the European pitches, was carried in the arms of the people, who, with great demonstrations of enthusiasm, accompanied the soccer stars at the Grande Hotel. In front of the hotel a large rally is being held by the sports institutions with the participation of all the social classes." ${ }^{2}$ In Rio de Janeiro, the fans came to meet Leônidas, all of them wanting to touch him and receive a hug or an autograph from the Black Diamond. Led from the port docks to the Botafogo ground, he was greeted by the fans in a tumult of people, which led to the player fainting, surrounded and squeezed by the crowd (Ribeiro, 20I0). Even after a few days had passed, the euphoria of the fans had not waned. More and more people were went after the star, asking for autographs and making all kinds of requests. What became apparent was that wherever he went, Leônidas drew large crowds, especially the 'young women,' who, when they passed by the star: "Stopped, looked at Leônidas, and then carried on their way up and down the avenue, content, as though they had seen a cinema idol" (Rodrigues Filho, 2010: 212).

Indeed the idolization of Leônidas was such that the star received a series of prizes. For example, he won a car after winning first place in a competition run by Magnólia cigarettes, the most popular cigarette of the period. Launched in September I937, the idea behind the competition was to choose Rio de Janeiro's most popular soccer player. To take part, fans had to buy a pack of the cigarette brand, write the name of the player of their preference and send it to the manufacturer. In the campaign for the prize, Leônidas distributed ballot boxes throughout the city $^{\mathrm{I} 3}$ and encouraged people to buy Magnólia cigarettes: "I want to make a suggestion. I think my idea's a good one. I want Flamengo's members and fans to send me just one empty pack of 'Magnólia' each week. As you know, the number of Flamengo fans is huge and a pack from each one, added up in the end, will be enough for my Chevrolet. The rest is easy." ${ }^{\text {I4 }}$ 
Among other schemes, he came up with an unusual idea to boost his chances of victory in the competition: "Leonidas was the star who had the laudable initiative of visiting the Detention Centre to distribute 'Magnólia' cigarettes, which friends who did not smoke sent him." ${ }^{15}$ Leônidas's popularity was unrivalled and the Flamengo fanbase was already the largest in the city. The end result: almost 300,000 cigarette packs with the name of the star, who won the competition easily (Ribeiro, 2010).

With his newfound prestige, Leônidas began to give talks throughout the country in which he recounted the goals scored in the I938 World Cup and spoke about Brazilian football. The first was held in the João Caetano Theatre in Rio de Janeiro. Announcing the event, Jornal dos Sports reported: “The 'Black Diamond' will describe to his fans in detail the seven goals that he scored masterfully over the course of the 'Coupe du Monde."” ${ }^{16}$ O Globo reported that: "A unique show will provide the festive occasion tonight at the João Caetano Theatre, sponsored by Leonidas, in order to raise funds for the Union of Blind People of Brazil." ${ }^{\text {I7 }}$ The newspaper also reported that the second part of the show would feature Ary Barroso, who would be accompanied by some of the big names from Brazilian music and radio, like Benedito Lacerda and Carlos Galhardo. Days later, another talk was given by the football star to the public of Belo Horizonte. Procópio Ferreira organized the event and covered all the expenses. Leônidas received half of the revenue. In the first part of the talk, he read a text written by his friend and journalist José Maria Scassa; next he drew all seven goals scored in the World Cup on a blackboard located on the centre of the stage. That night Leônidas wore a smoking jacket offered by Sapataria Capital as part of an advertising campaign (Ribeiro, 2010).

As happens with celebrities today, the striker participated actively in the advertising market and in the promotion of sales and business. First were the store openings. Every establishment wanted the presence of the biggest idol of Brazilian soccer as a way to boost their sales. And Leônidas went to various. He "would lose ten minutes, the time needed to take a photograph, open a bottle of champagne, in the inauguration of a shoe shop, [paid] a pocketful of gold" (Rodrigues Filho, 2010: 22I). The I938 World Cup success, which turned Leônidas into a national celebrity, led to diverse tributes from commercial establishments, which sought to associate their products with the star's image. These episodes were frequently reported in the press; as in the report "A gift to Leonidas: the offer from Fabrica Metallurgica Brasileira," published by O Globo newspaper:

The brilliant performances of Leonidas in the games that our team played in the Old World, established him as one of the world's most perfect footballers. This fact generated exceptional enthusiasm in our country, and various stores, excited by the remarkable feat of the 'Black Diamond,' have offered him gifts, which will be delivered when he returns to Rio. Fabrica Metallurgica Brasileira, associating itself with these tributes, has just offered the Flamengo player a chrome lamp with a green porcelain 
spotlight, suitable for an office, which is on display in one of the windows of its store at Rua da Carioca $53 .{ }^{18}$

The tributes presented to the star in exchange for advertising were constant. The report "A regal present for Leonidas: Offered to the glorious football star by the firm J. M. Mello \& Cia, a famous bathroom set of green porcelain"19 informed readers that "The famous 'Hornberg' set was offered to Leonidas in a demonstration of recognition of the great achievements of our glorious 'scorer."

\section{Um presente regio para Leonidas}

\section{OFFERECIDO AO GLORIOSO ASTRO DO FOOTBALL, PELA FIRMA J. M. MELLO \& CIA., UM FAMOSO CONJUNTO DE QUARTO DE BA. NHEIRO DE LOUÇA VERDE}

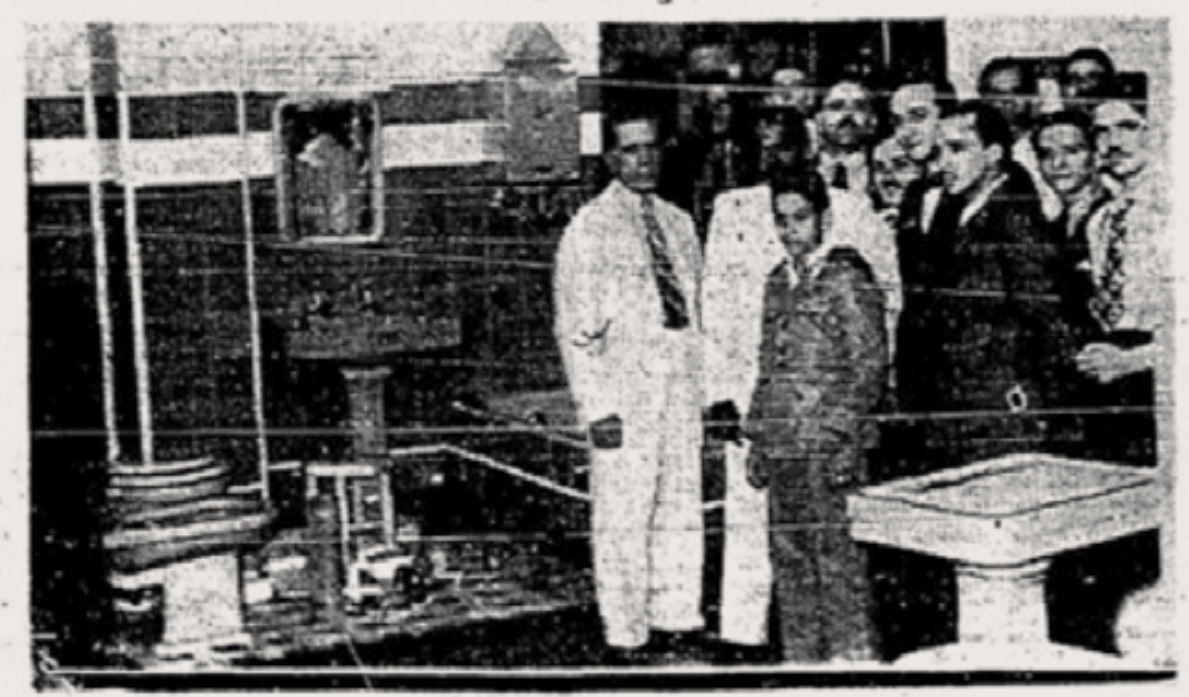

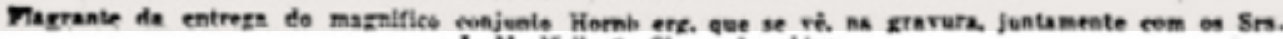
J. M. Jfello of Cia. Leobidas

I

Report on the present offered by J. M. Mello \& Cia to the football star Leônidas

Source: O Globo, I8 August I93 
Another example was reported in the news story "For Leonidas the 'Paragon' chronograph." 20 "As we have been reporting, Messrs. Coimbra \& Fuah, representatives for Brazil of the famous 'Paragon' watches, offered an expensive 'Paragon' chronograph to the player who scored the first goal for Brazil in the 'Copa Roca' match (...) Leonidas, the centre-forward for Flamengo, won the valuable 'Paragon' chronograph, which will be handed to him at the Jornal dos Sports newsroom."

In response to all these actions and the constant pressures from the brands, Leônidas ended up making some free adverts for stores and companies. The soccer star saw no difference between giving his autograph and signing a paper for a friend asking him for this favour. As a result, he ended up lending his name to diverse adverts without requesting any kind of fee for use of his image. On one such occasion, "the entrepreneur Manoel de Brito asked Leônidas to sign a declaration saying that he only ate Peixe guava sweet. The advert was in all the newspapers, taking up at least a quarter page" (Ribeiro, 2010: I34) and the payment was a box of guava sweet for Leônidas (see next page).

At the height of his fame, Leônidas was advised by José Maria Scassa. The latter explained that giving autographs or writing messages in supporter albums or those belonging to female fans was something he could do. But signing an advert for a product was work for which he should be duly remunerated, since the companies were using his image and popularity to make large sums of money. Leônidas not only agreed with Scassa, he invited the journalist to negotiate his advertising contracts. This was the first time that a Brazilian footballer would be employed as an official garoto-propaganda, a 'poster boy,' for companies, products and services (Ribeiro, 20I0). It was probably at this moment too that the figure of the agent or entrepreneur emerged, responsible for the commercial contracts of sports celebrities. One of the first contracts signed was with Lacta, which, soon after the I938 World Cup, decided to launch the Diamante Negro (Black Diamond) chocolate, making use of the player's nickname. Like any contemporary celebrity, in this context, the name or nickname of Leônidas was capable of selling anything, including chocolates (see page 8I4):

Ary Silva, present at the meeting, saw the magnate pay money for the use of Leônidas's nickname for one of his chocolates. This detail is important as it shows that use of the Diamante Negro label by the chocolate factory was made with the player's consent, even though Lacta has frequently been accused of never giving anything to Leônidas. Ary Silva does not know how much, he recalls that some spoke about 2 contos, but one thing he is certain about, he saw Leônidas receive a 'fistful' of money from the hands of the magnate. The São Paulo journalist also saw Leônidas sign a contract that would entitle him to receive a share of the sales of Diamante Negro chocolate (Ribeiro, 20I0: 135). 
Leonidas, o supremo "Crack" brasileiro, hoje mundialmente famoso, recommenda a goiabada marca PEDXE aos esportistas do Brasil cOMO a SOBREMESA MELHOR DO MUNDO...

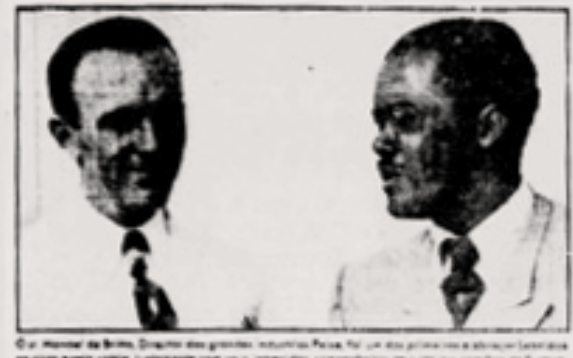

Mesmint oas inotusious, out

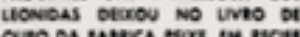

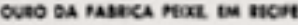

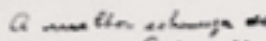

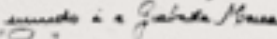

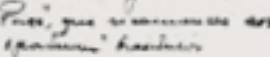

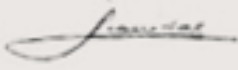

순.

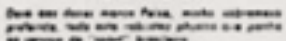
Ponver

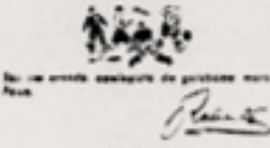

$=\frac{\cos ^{5}}{11}$

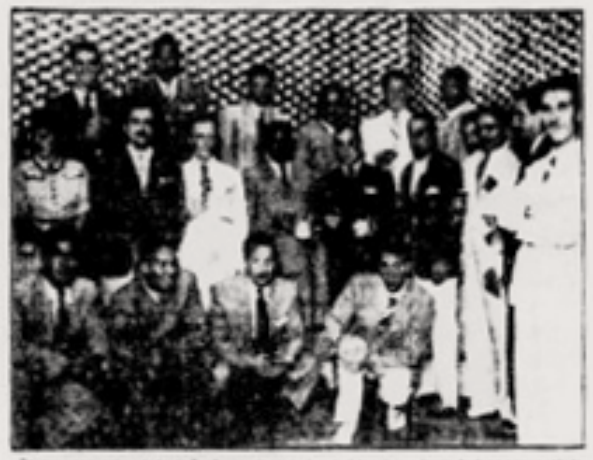

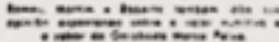

Rner:

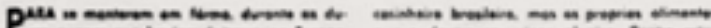

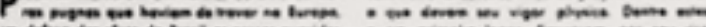

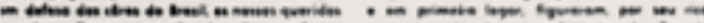

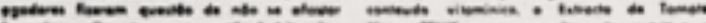

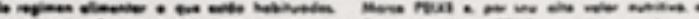

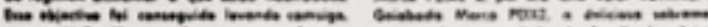

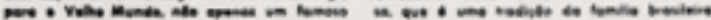

\section{Mancarruste

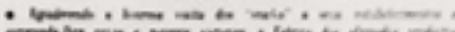

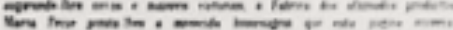

\section{Goiabada}

Imatel PEIXE

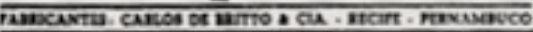

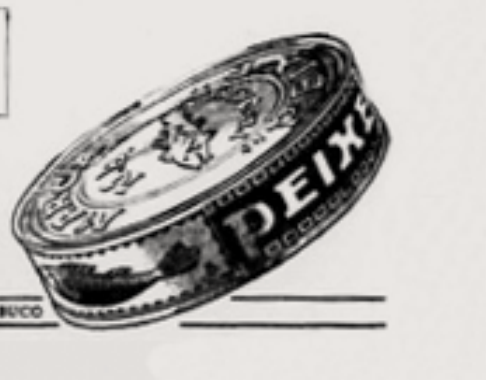




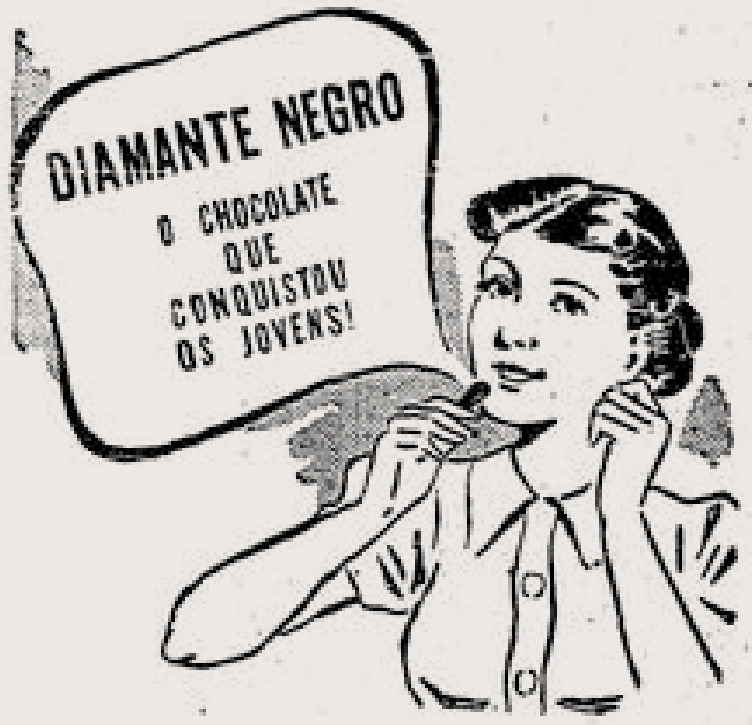

- Constituindo una novidade pelo seu delieioso sabos e typo de fabricastalo, o cbocolato "Diamante Negro" conquistod rapidaento un consideravel numero do aprecisdores. "Diamante Negro", alem do seu delicisoo pa- ledst, tem as qualidades sltameate notritixas do mel e das amendcas que eatram tom aua composição. E' c alimento indieado aos espottistas para sestauras ss esergias dispendioss bas onepetiḡes.

*

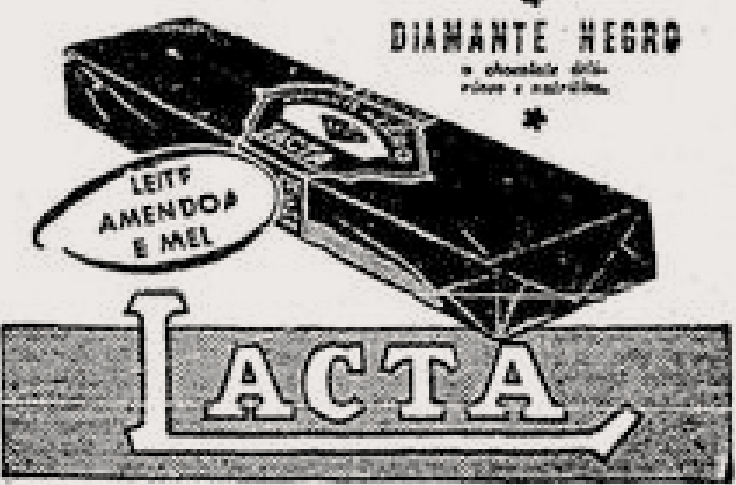


In another example, the Sudan Company, the country's largest cigarette manufacturer in the I930s and I940s, paid I5 contos for the right to print Leônidas's name on its cigarettes. On this occasion, the news item “'Diamante Negro' dispatches to São Paulo today," ${ }^{21}$ published in Jornal dos Sports, reported that the player would receive tributes in the São Paulo capital and would head to Campinas, where the business magnate Sabbado D'Angelo would offer him the sponsorship of Leonidas cigarettes, created in honour of the star player. During the same period, a watch with his name was launched on the market (Ribeiro, 2010).

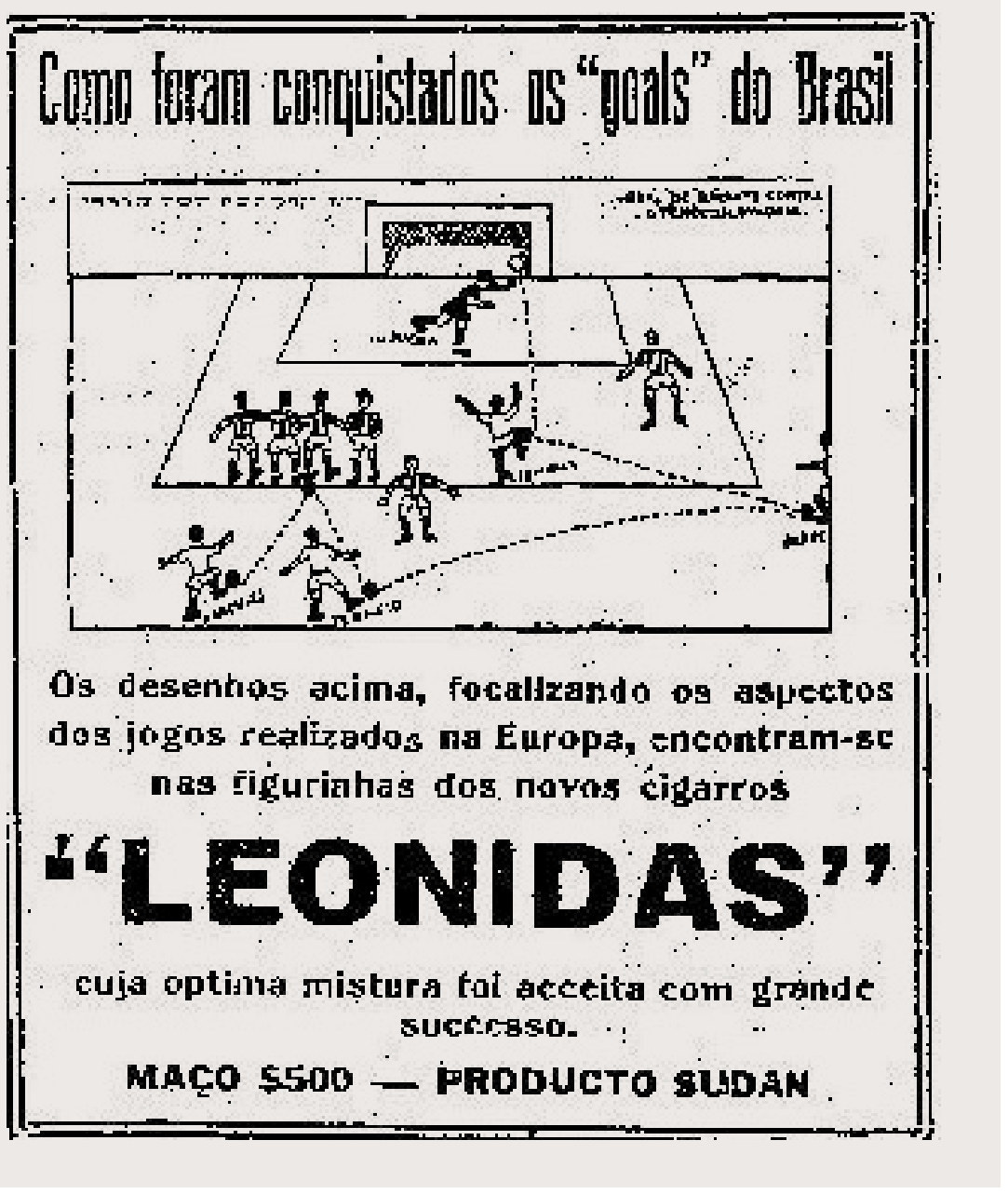

4 Advertisement for Leonidas cigarettes

Source: O Globo, 5 September I938 
These examples reveal that in order to lure consumers, the advertising market in the I930s and I940s sought to associate products, stores and brands with the image of Brazil's leading sports celebrity: the striker Leônidas. From the perspective of the anthropology of consumption, we argue that goods function as both walls and bridges, since they are bearers of meaning and can be used both for inclusion in spaces and groups and for exclusion of the undesired. Relating with each other, goods construct meanings, enable social relations and represent identities and lifestyles (Douglas \& Isherwood, 2004). In this sense, advertising acts in accordance with the logic of totemic systems - which create similarities and differences between opposing spheres - and mediate between production and consumption in order to confer meaning to goods (Rocha, I985). Advertising makes use of diverse strategies: one of them involves appropriating the prestige of celebrities and associating their public images with the products offered to consumers (McCracken, 2012), investing in a 'prestigious imitation' (Mauss, I974). It is this system of consumption in action that we see being deployed for the first time with soccer in the case of Leônidas.

There were countless advertisements for products, services and stores, inaugurations, participations in social festivities or marketing campaigns rubberstamped with the prestige obtained by playing football. Brazil's incipient 'star system' began to include agents who did not come from the traditional model of art, politics or the media. A black footballer who was just as popular as President Getúlio Vargas was a significant novelty, one until then unknown in Brazilian society. Competing in commercial activities outside the sports profession properly speaking with people like Ary Barroso, Mário Lago, Linda Batista, Paulo Gracindo, Carmen Miranda, Procópio Ferreira or Grande Otelo implied a significant transformation in the markets - a signal that they were expanding, opening up new models for perpetuating themselves and including new agents.

Leônidas was a figure who, though he did not create, was nonetheless a catalyser of many things. Three of them stand out clearly in his trajectory. On the pitch, undoubtedly, moments as stunning as the elastic movement of his bicycle kick or the skilful dribbling that transformed the opponent's certainties into an optical illusion. Off the pitch, he catalysed experiences, identities and ideologies of Brazilianness for which his body became a canvas and to which his soccer exploits gave consistency and concreteness. In the marketplace, he inaugurated the idea that a specific skill on a particular stage - football - could be used to sell things as disparate or paradoxical as cigarettes, watches or chocolates. Moreover, Leônidas and his circumstances defined a type of space in culture - one authorized by the celebrity seal of approval - that ceased thereafter to be limited to artists, actors and singers and became accessible to sports professionals in Brazil too. Until Leônidas, there were no sports celebrities. Before him no money circulated in the sports universe beyond what was obtained from the practice itself, no prestige beyond the small amount offered 
only by the initiated. After Leônidas, sport in Brazil acquired a new significance as business. Since then and especially in the present, what was incipient has become responsible for producing all kinds of celebrities and multiple markets that sustain and are sustained by them.

Received on 24/4/20I7 | Revised on 4/9/20I7 | Approved on 6/9/2017

Everardo Rocha is Associate Professor of the Postgraduate Program in Communications of PUC-Rio, a CNPq level ID researcher, participant of the FAPERJ Our State Scientist program,and holder of an MA (I982) and PhD (I989) in anthropology from PPGAS/Museu Nacional/UFRJ. He is the author of diverse books, among them Magia e capitalismo: um estudo antropológico da publicidade (1985); A sociedade do sonho: comunicação, cultura e consumo (I985); Representações do consumo: estudos sobre a narrativa publicitária (2006); and o paraíso do consumo: Émile Zola, a magia e os grandes magazines (2016).

William Corbo is a doctoral student in Communications on the Postgraduate Program in Communications of PUC-Rio, a substitute professor of the Department of Sociology at IFCS/ UFRJ and co-author of the book O paraíso do consumo: Émile Zola, a magia e os grandes magazines (20I6). 


\section{NOTES}

I In newspaper reports from the I930s and I940s, the name Leônidas appears without the circumflex accent (Leonidas). Despite this fact, we have opted to write his name with an accent as it appears in the studies consulted for this article.

2 The question of Leônidas being a black player in an environment rife with racial prejudices, football included, has already been studied by Gordon (1995), Pereira (2000) and Souza (2008), among others, as well as the classic $O$ negro no futebol brasileiro, by Mário Rodrigues Filho (2010). In the case of the present article, another aspect of Leônidas's trajectory will be emphasized: his immense success in advertising and the impact he had on Brazilian culture in general.

3 For a wide-ranging review of studies of consumption, including works by historians, see Rocha, Frid \& Corbo (20I6).

4 O Globo, I5 January I934.

5 The dispute between amateurism and professionalism was intense in the context of Brazilian football in the I930s. Consequently, the Brazilian national squad was assembled in improvised form for the 1934 World Cup.

6 Numerous explanations exist for the emergence of the nickname Diamante Negro (Black Diamond). In a statement to the newspaper Última Hora in 1964, Leônidas confirmed the idea that the French had invented this nickname after his standout performance in the 1938 World Cup. However, earlier newspaper items, such as the issue of Jornal dos Sports published on December $7^{\text {th }}$, I932 already acclaimed Leônidas as the Black Diamond.

7 O Globo, 7 July 1938.

8 O Globo, 28 June 1938.

9 The 1938 World Cup would be the last featuring Leônidas, since the two following editions - I942 and I946 - were suspended due to the Second World War.

Io O Globo, II April 1937.

I I O Globo, 24 June 1938.

I2 O Globo, 8 July I938. 
I3 Jornal dos Sports, Io December 1937.

I4 Jornal dos Sports, 26 October 1937.

I5 Jornal dos Sports, 3 February 1938

I6 Jornal dos Sports, 23 July I938.

I7 O Globo, 23 July 1938.

I8 O Globo, I4 July I938.

I9 O Globo, I8 August I938.

20 Jornal dos Sports, I9 February 1940.

2I Jornal dos Sports, 24 July 1938.

\section{BIBLIOGRAPHY}

Amaro, Fausto \& Helal, Ronaldo. (20I4). Futebol, corpo e publicidade: um estudo de caso. Comunicação, Mídia e Consumo, São Paulo, II, p. I39-I6I.

Araújo, Ricardo Augusto Benzaquen de. (I994). Guerra e paz: Casa-Grande \& Senzala e a obra de Gilberto Freyre nos anos 30. Rio de Janeiro: Ed. 34.

Araújo, Ricardo Augusto Benzaquen de. (I980). Os gênios da pelota: um estudo do futebol como profissão. Dissertação de Mestrado. PPGAS/Museu Nacional/Universidade Federal do Rio de Janeiro.

Armstrong, Gary \& Giulianotti, Richard (ed.). (I999). Football cultures and identities. London: Palgrave MacMillan.

Barthes, Roland. (2003) [1957]. Mitologias. São Paulo: Difel. Baudrillard, Jean. (I993) [I968]. O sistema dos objetos. São Paulo: Perspectiva.

Baudrillard, Jean. (I99I) [I970]. A sociedade de consumo. Lisboa: Edições 70 .

Campbell, Colin. (200I). A ética romântica e o espírito do consumismo moderno. Rio de Janeiro: Rocco.

DaMatta, Roberto. (2006). A bola corre mais que os homens: duas copas, treze crônicas e três ensaios sobre futebol. Rio de Janeiro: Rocco.

DaMatta, Roberto. (I982). Esporte na sociedade: um ensaio sobre o futebol brasileiro. In: Universo do futebol: esporte e sociedade brasileira. Rio de Janeiro: Pinakotheke, p. I9-42. 
Damo, Arlei Sander. (2012). Lo econômico e lo simbólico en fútbol mercantilizado: una interpretación antropológica. Cuadernos de Ciencias Sociales de FLACSO Cuesta Rica, I60, p. 7I-Io6. Damo, Arlei Sander. (20II). Produção e consumo de megaeventos esportivos: apontamentos em perspectiva antropológica. Comunicação, Mídia e Consumo, São Paulo, 8, p. 67-92.

Damo, Arlei Sander. (2009). O simbólico e o econômico no futebol de espetáculo: as estratégias da Fifa para tornar as copas lucrativas a partir de uma interpretação antropológica. Razón y Palabra, 69, p. I-25.

Damo, Arlei Sander. (2008). Dom, amor e dinheiro no futebol de espetáculo. Revista Brasileira de Ciências Sociais, 23, p. I39-I50. Damo, Arlei Sander \& Oliven, Ruben George. (2014). Megaeventos esportivos no Brasil: um olhar antropológico. Campinas: Autores Associados.

Douglas, Mary \& Isherwood, Baron. (2004). O mundo dos bens: para uma antropologia do consumo. Rio de Janeiro: Ed. UFRJ.

Duke, Vic. (I99I). The sociology of football: A research agenda for the I99os. The Sociological Review, 39/3, p. 627-645.

Fausto, Boris. (2006). Getúlio Vargas: o poder e o sorriso. São Paulo: Companhia das Letras.

França, Vera. (20I4). Celebridades: identificação, idealização ou consumo? In: França, Vera et al. Celebridades no século XXI: transformações no estatuto da fama. Porto Alegre: Sulina, p. I5-36. Freyre, Gilberto. (20I0) [1947]. Prefácio à Ia edição. In: Rodrigues Filho, Mário. O negro no futebol brasileiro. Rio de Janeiro: Mauad, p. 24-26.

Freyre, Gilberto. (I975) [I933]. Casa-grande \& senzala. Rio de Janeiro: José Olympio.

Freyre, Gilberto. (1938). Foot-ball mulato. Diário de Pernambuco. Recife, p. 4.

Gastaldo, Édison. (2002). Pátria, chuteiras e propaganda: o brasileiro na publicidade da Copa do Mundo. São Paulo: AnnaBlume.

Gordon, Cesar. (I995). História social dos negros no futebol brasileiro. Pesquisa de Campo. Rio de Janeiro, 2, p. 7I-90.

Guedes, Simoni Lahud. (I977). O futebol brasileiro: instituição zero. Dissertação de Mestrado. PPGAS/Museu Nacional/Universidade Federal do Rio de Janeiro. 
Helal, Ronaldo. (1997). Passes e impasses: futebol e cultura de massa no Brasil. Petrópolis: Vozes.

Helal, Ronaldo et al. (20I4). Futebol-arte e consumo: as narrativas presentes na campanha "Ouse ser brasileiro". Revista Eletrônica do Programa de Pós-Graduação em Mídia e Cotidiano, 4, p. 88-104.

Hollanda, Bernardo Borges Buarque de. (2010). O clube como vontade e representação: o jornalismo esportivo e a formação das torcidas organizadas de futebol do Rio de Janeiro. Rio de Janeiro: 7Letras.

Hollanda, Bernardo Borges Buarque de. (2004). O descobrimento do futebol: modernismo, regionalismo e paixão esportiva em José Lins do Rego. Rio de Janeiro: Biblioteca Nacional.

Hughson, John et al. (ed). (2017). Routledge Handbook of Football Studies. London: Routledge.

Leite Lopes, José Sérgio. (1994). A vitória do futebol que incorporou a pelada. Revista USP, 22, p. 64-83.

Lynd, Robert. (1936). Democracy's third estate: the consumer. Political Science Quarterly, 5I/4, p. 48I-5I5.

Lynd, Robert. (1934). The consumer becomes a "problem". The annals of the American Academy of Political and Social Science, I73, p. I-6.

Mauss, Marcel. (1974) [1934]. As técnicas corporais. In: Sociologia \& Antropologia. São Paulo: EPU/Edusp.

McCracken, Grant. (20I2). Cultura e consumo II: mercados, significados e gerenciamento de marcas. Rio de Janeiro: Mauad X.

McCracken, Grant. (2003). Cultura e consumo: novas abordagens ao caráter simbólico dos bens e das atividades de consumo. Rio de Janeiro: Mauad.

McKendrick, Neil; Brewer, John \& Plumb, John Harold. (I982). The birth of a consumer society and the commercialization of eighteenth century England. Bloomington: Indiana University Press.

Miceli, Sergio. (1978). Os Gaviões da Fiel: torcida organizada do Corinthians. RAE. Revista de Administração de Empresas, São Paulo, I8/2, p. 43-46.

Pandolfi, Dulce (org.). (I999). Repensando o Estado Novo. Rio de Janeiro: Ed. FGV. 
Pereira, Leonardo Affonso de Miranda. (2000). Footballmania: uma história social do futebol no Rio de Janeiro, I902-I938. Rio de Janeiro: Nova Fronteira.

Ribeiro, André. (2010). Diamante Negro: biografia de Leônidas da Silva. São Paulo: Cia. dos Livros.

Rocha, Everardo. (2006). Representações do consumo: estudos sobre a narrativa publicitária. Rio de Janeiro: Mauad.

Rocha, Everardo. (2003). Jogo de espelhos: ensaios de cultura brasileira. Rio de Janeiro: Mauad.

Rocha, Everardo (1985). Magia e capitalismo: um estudo antropológico da publicidade. Rio de Janeiro: Brasiliense.

Rocha, Everardo; Frid, Marina \& Corbo, William. (2016). O paraíso do consumo: Émile Zola, a magia e os grandes magazines. Rio de Janeiro: Mauad.

Rodrigues Filho, Mário. (2010 [1947]). O negro no futebol brasileiro. Rio de Janeiro: Mauad.

Rodrigues, José Carlos. (I982). O rei e o rito. Revista Comum, I, p. I6-29.

Sahlins, Marshall. (1979). Cultura e razão prática. Rio de Janeiro: Zahar.

Simmel, Georg. (1904). Fashion. International Quarterly, ıо, p. I30-I55.

Sodré, Muniz. (1977). Futebol, teatro ou televisão. In: O monopólio da fala. Petrópolis: Vozes.

Sombart, Werner. (1967) [1913]. Luxury and capitalism. Ann Arbor: University of Michigan Press.

Souza, Denaldo Alchorne de. (2008). O Brasil entra em campo: construções e reconstruções da identidade nacional (I9301947). São Paulo: Annablume.

Toledo, Luiz Henrique de. (2002). Lógicas no futebol. São Paulo: Hucitec/Fapesp.

Toledo, Luiz Henrique de. (200o). No país do futebol. Rio de Janeiro: Zahar.

Toledo, Luiz Henrique de. (I996). Torcidas organizadas de futebol. Campinas: Autores Associados/Anpocs.

Veblen, Thorstein. (1965) [1899]. A teoria da classe ociosa: um estudo econômico das instituições. São Paulo: Pioneira. 
Palavras-chave

Consumo e narrativa

publicitária;

fama e celebridade;

Leônidas da Silva;

cultura brasileira;

história do consumo.
Keywords

Consumption and advertising narratives;

fame and celebrity;

Leônidas da Silva;

Brazilian culture; history of consumption.
O CRAQUE DA BOLA E O MUNDO DOS BENS: FUTEBOL E CONSUMO NA IMAGEM PÚBLICA DE LEÔNIDAS DA SILVA

\section{Resumo}

Este trabalho analisa o lugar ocupado por Leônidas da Silva no mercado publicitário nas décadas de i930 e I940, auge de sua carreira como jogador de futebol. Trata-se de investigar as formas pelas quais, naquele contexto, consumo e narrativa publicitária se apropriaram do futebol para expandir hábitos de compra e, simultaneamente, aumentar a popularidade e potencializar a dimensão espetacular do esporte. Leônidas era uma celebridade da época e, como tal, inaugurou lojas, estrelou anúncios, foi garoto-propaganda de algumas marcas e emprestou seu nome para produtos de sucesso. A construção de sua figura midiática revela um modelo de articulação entre esporte e consumo que, gestado na primeira metade do século XX, segue permeando o imaginário contemporâneo em um processo de transformação de craques do "universo do futebol" em estrelas do "mundo dos bens".

\section{A STAR PLAYER AND THE WORLD OF GOODS: SOCCER AND CONSUMPTION IN THE PUBLIC IMAGE OF LEÔNIDAS DA SILVA}

\section{Abstract}

This work analyses the place occupied by Leônidas da Silva in the advertising market of the I930s and I940s, when he was at the peak of his career as a football player. We investigate how consumer habits and advertising narratives appropriated soccer in order to expand purchasing conventions and increase the sport's popularity and entertainment potential. Leonidas was a celebrity during this era and, like other celebrities, he would inaugurate stores, feature in adverts for various brands and lend his name to successful products - such as 'Cigarro Leônidas' and 'Diamante Negro.' The construction of his media image reveals a model of articulation between sports and consumption that took form in the first half of the twentieth century and continues to permeate the contemporary imagination, transforming outstanding footballers into stars of the 'world of goods.' 